\title{
Inovasi Buku Ajar Kimia SMA/MA Kelas XI Semester Ganjil Terinternalisasi Nilai-Nilai Karakter Siswa
}

\author{
Riska Ritonga1*; Ajat Sudrajat² dan Eddiyanto² \\ ${ }^{1}$ Program Studi Pendidikan Kimia, Pascasarjana, Universitas Negeri Medan, Medan \\ 2Jurusan Kimia, FMIPA, Universitas Negeri Medan, Medan \\ *Korespondensi: rizka.ritonga@gmail.com
}

\begin{abstract}
This study aims to determine: (1) Test the feasibility of High School Class XI textbook commercially complies with the standards BSNP; (2) Test the feasibility of textbook by validators to high school chemistry textbook/ MA first semester of classes XI developed in accordance with the standards BSNP; (3) Test the feasibility of textbook by validators to high school chemistry textbook/MA Class XI the first semester have developed internalized the values of the character of the students; (4) Test the feasibility of textbook by students of the high school chemistry textbook/ MA class XI semester of internalized character values of students; (5) Improved student learning outcomes after studying with a high school chemistry textbook/ MA class XI semester of internalized character values of students; (6) The results of studying chemistry student using high school chemistry textbook / MA class $X I$ semester of internalized character values of students better than the minimum completeness criteria. The entire sample was selected by purposive sampling. Samples were determined in this study are (1) high school chemistry book/ MA Class XI outstanding as much as four books; (2) Teachers chemistry with the criteria of formal education bachelor and experienced teaching in schools as many as 10 people, chemistry lecturer criteria have minimal formal education postgraduate were 3 people; (3) A Class XI Sains-treated using a textbook teaching high school chemistry/ MA class XI half of Odd internalized character values of students based on curriculum 2013. Based on test data analysis, the results showed that (1) Test the feasibility of commercially textbooks valid criteria and should be revised; (2) Test the feasibility of the validator against chemical textbook produced in this study meet the standards required by the National Education Standards. (2) and (3) test the feasibility of the validator and students to the textbook internalized character values of students in this study meet the standard of assessment rubrics character values developed. (4) Improved student learning outcomes using chemistry textbook produced in this study is of o.69 which is average. (5) Based on data obtained learning outcomes sign value <0.05 (o.011 <0.05) the use of high school chemistry textbook/ MA class $X I$ half of Odd internalized the values of the student's character better than the the minimum completeness criteria.
\end{abstract}

Keywords: Buku ajar kimia, terinternalisasi nilai-nilai karakter siswa

\section{PENDAHULUAN}

Pendidikan adalah salah satu bentuk perwujudan dari seni dan budaya Manusia yang dinamis dan syarat akan perkembangan. Para pemikir pendidikan Indonesia saat ini sedang mencari dan merumuskan dasar-dasar dari sistem yang dapat membangun masyarakat Indonesia yang baik karakter nasional sebagai ciri masyarakat yang beradab, bermartabat dan modern (Amir, 2013). Pendidikan memiliki permasalahan yang berintikan pada proses pembelajaran. Pembelajaran merupakan proses interaksi peserta didik dengan pendidik dan sumber belajar pada lingkungan belajar (UU No 20 Tahun 2003 tentang Sisdiknas).

Pemerintah melalui Menteri Pendidikan dan Kebudayaan melakukan langkah revitalitas sistem pendidikan yang selama ini berjalan menjadi pendidikan karakter melalui pengembangan kurikulum 2013. Pendidikan karakter dalam kurikulum 2013 bertujuan untuk meningkatkan mutu proses dan hasil pendidikan yang mengarah pada pembentukan budi pekerti dan akhlak mulia peserta didik secara utuh, terpadu dan seimbang, sesuai dengan standar kompetensi lulusan pada setiap satuan pendidikan (Mulyasa, 2013). Pengembangan Pendidikan karakter sangat strategis bagi kelangsungan dan keunggulan bangsa di masa mendatang (Afandi, 2011).

Pendidikan karakter di sekolah selama ini baru menyentuh pada tahap pengenalan norma atau nilai-nilai, dan belum pada internalisasi dan tindakan nyata dalam kehidupan sehari-hari (Putra, 2013). Salah satu yang berpengaruh terhadap proses pembelajaran adalah buku yang digunakan oleh siswa maupun guru. Penyebab belum terlaksananya pembelajaran IPA terpadu 
adalah tidak tersedianya bahan ajar, guru dihadapkan dengan krisis karakter pada siswa (Wibawa, 2013). Sebagai salah satu media belajar yang banyak dipakai, buku memiliki peran penting dalam menentukan hasil belajar siswa dalam hal pembentukan karakter. Pengembangan buku ajar dengan menginternalisasikan nilai-nilai karakter ke dalam mata pelajaran dimaksudkan agar pada diri siswa di samping menguasai kompetensi yang berkaitan dengan materi ajar, diharapkan juga dapat berkembang nilai-nilai karakter mulia siswa sehingga tujuan Pendidikan Nasional dapat terwujud.Berdasarkan permasalahan diatas, peneliti bermaksud untuk melakukan pengembangan buku ajar Kimia SMA/MA kelas XI. Dengan demikian, penulis melakukan pengembangan buku ajar dengan judul penelitian "Inovasi Buku Ajar Kimia SMA/MA Kelas XI Semester Ganjil Terinternalisasi Nilai-nilai Karakter Siswa”.

\section{METODE}

Subjek penelitian yang ditetapkan pada penelitian ini adalah 4 buku yang beredar di pasaran dengan penerbit yang berbeda. 10 orang guru kimia di SMA/MA baik Negeri maupun swasta yang ada di Sumatera Utara dan 3 orang Dosen kimia yang dipilih secara purposive sampling. Guru kimia yang memiliki kriteria pendidikan formal minimal S1 dan pengalaman mengajar minimal 3 tahun di sekolah tempat penelitian. Dosen dipilih dengan kriteria pendidikan minimal S2, memiliki pengalaman minimal 5 tahun, sedang aktif mengajar dan menguasai materi Kimia Dasar yang relevan dengan materi kimia SMA. Penelitian ini termasuk penelitian pengembangan (research and development) yang dimodifikasi dari pengembangan pembelajaran model Borg \& Gall. Penelitian pengembangan (research and development) merupakan penelitian yang digunakan untuk menghasilkan produk tertentu dan menguji keefektifan produk tersebut (Sugiyono, 2010).

Data pada penelitian ini terdiri dari data kualitatif dan data kuantitatif, sehingga analisis data dilakukan dengan mengolah masing-masing data. Untuk data kualitatif dianalisis deskriptif presentasi. Analisis deskripsi presentasi digunakan untuk mendeskripsikan presentase masing-masing variabel. Dalam analisis deskriptif presentase ini perhitungan yang digunakan untuk mengetahui tingkat presentase skor jawaban dari masing-masing sampel dengan skala penilaian yang akan digunakan adalah 1 sampai 5 .

Efektifitas penggunaan buku ajar yang dikembangkan terhadap hasil belajar digunakan rumus nilai gain. Sebagaimana yang diungkapkan Hake (1998) bahwa dengan nilai rata-rata gain yang ternormalisasi maka secara kasar dapat mengukur efektifitas suatu pembelajaran dalam pemahaman konseptual. Untuk menunjukkan hasil belajar kimia siswa yang menggunakan buku ajar kimia SMA/MA kelas XI semester ganjil terinternalisasi nilainilai karakter siswa lebih baik dari nilai KKM peneliti menggunakan uji $t$ dengan satu sampel (One Semple T-Test) yaitu membandingkan nilai hasil postest dengan nilai KKM.

\section{HASIL DAN PEMBAHASAN}

\section{Deskripsi umum penelitian}

Tahap awal pada penelitian ini dilakukan pengembangan buku ajar kimia SMA/MA berdasarkan kurikulum 2013. Pengembangan buku ajar ini disesuaikan dengan KI dan KD kimia SMA/MA kelas XI semester ganjil. Buku ajar kimia hasil pengembangan terdiri atas pokok bahasan dan sub pokok bahasan sesuai kurikulum 2013. Selanjutnya setiap pokok bahasan terinternalisasi dengan nilai-nilai karakter siswa. Data yang dideskripsikan dalam penelitian ini meliputi data: (1) Analisis awal buku ajar kimia kelas XI semester ganjil dari 4 penerbit yang berbeda dengan menggunakan rubrik BSNP; (2) Analisis terhadap buku ajar yang telah dikembangkan berdasarkan kurikulum 2013 dan BSNP (Badan Standar Nasional Pendidikan) oleh 3 dosen dan 10 guru kimia; (3) Penilaian Buku ajar sesuai dengan internalisasi karakter oleh validator; (4) Penilaian Buku ajar sesuai dengan internalisasi karakter oleh siswa; (5) Perolehan nilai siswa pada pokok bahasan kesetimbangan kimia dengan dan tanpa bahan ajar yang telah dikembangkan.

\section{Analisis buku ajar kimia}

Buku ajar kimia yang beredar di pasaran dianalisis oleh peneliti dengan menggunakan uji standarisasi berdasarkan BSNP. Buku ajar yang dianalisis berjumlah 4 buku yang berbeda pengarang dan penerbit diinisialkan buku A, B, C, dan D. Tingkat kelayakan 4 buku yang telah dianalisis berdasarkan BSNP nilai rata-rata untuk uji kelayakan isi sebesar 3,3, untuk uji kelayakan bahasa sebesar 3,65, 
untuk uji kelayakan penyajian sebesar 3,25, dan untuk uji kelayakan kegrafikaan sebesar 3,308. Dilihat dari kriteria validitasnya bahwa buku tersebut cukup valid tetapi perlu direvisi. Selain itu, buku yang di analisis belum menunjukkan adanya nilai-nilai karakter dalam keempat buku tersebut.

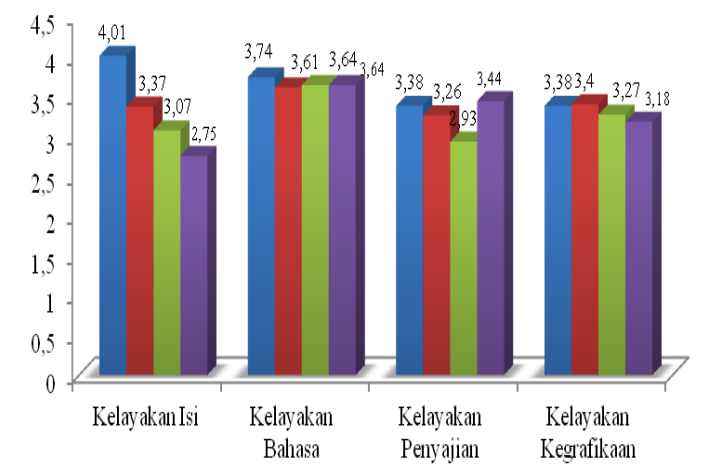

Gambar 1. Analisis nilai rata-rata uji kelayakan 4 buku berdasarkan BSNP

\section{Buku ajar kimia terinternalisasi nilai-nilai karakter siswa}

Penelitian pengembangan buku ajar kimia SMA/MA kelas XI semester ganjil terinternalisasi nilai-nilai karakter siswa adalah Research and Development (R\&D). Hasil penelitian ini terdiri atas pengembangan buku ajar kimia yang dilakukan melalui penyusunan materi, nilai-nilai karakter, contoh dalam kehidupan sehari sehingga siswa dapat mengetahui kegunaan kimia dalam kehidupannya dan berdasarkan saran dari dosen pembimbing dan guru kimia. Tahap awal dalam pengembangannya adalah membuat konsep buku ajar kimia yang menyenangkan dan menarik para siswa untuk membacanya serta pada saat membacanya akan membangkitkan karakter-karakter yang baik pada siswa.

Setelah membuat konsep pada buku ajar kimia tahap selanjutnya yaitu membuat buku ajar kimia SMA/MA kelas XI semester ganjil terinternalisasi nilai-nilai karakter siswa. Dalam membuat buku ajar kimia, peneliti memperhatikan beberapa hal mengenai buku ajar yaitu, materi ataupun teori yang ada haruslah dibarengi dengan contoh dalam kehidupan sehari-hari sehingga siswa mengetahui bahwa pelajaran kimia bukanlah pelajaran yang abstrak serta saran-saran yang disampaikan dosen pembimbing dan para guru. Hal ini sejalan dengan Madiansyah (2013) Pendidikan karakter bagi siswa bertujuan untuk melatih pembiasaan nilainilai karakter yang baik dalam kehidupan sehari-hari. Oleh karena itu, pengembangan nilai karakter dalam pembelajaran diperlukan adanya perangkat pembelajaran yang mendukung pengintegrasian nilai-nilai karakter.

Pengembangan buku ajar kimia SMA/MA kelas XI semester ganjil terinternalisasi nilainilai karakter siswa memiliki karakteristik yaitu dalam penggunaan buku ajar tersebut memberikan analogi materi pelajaran pada siswa dengan contoh-contoh yang dapat ditemukan siswa dalam kehidupan seharihari, kemudian terinternalisasi nilai-nilai karakter dalam setiap bab baik materi, uji coba praktikum, tugas, maupun peranannya dalam kehidupan sehari-hari yang dapat dimanfaatkan dengan sebaik-baiknya oleh para siswa.

Dalam pengembangannya buku ajar ini dibuat semenarik mungkin. Materi yang dicantumkan berupa Hidrokarbon dan minyak bumi, Termokimia, Kinematika Kimia (Laju Reaksi) dan Kesetimbangan Kimia. Buku ajar ini terdiri dari 208 halaman, dilengkapi dengan kata pengantar, standar isi dan kompetensi 2013, karakteristik buku, daftar isi, materi pengantar materi, peta konsep, internalisasi karakter siswa yang berhubungan dengan pokok bahasan, kecakapan ilmiah (praktikum), fakta-fakta ilmiah disekitar kita juga situs web yang bisa dikunjungi siswa untuk pendalaman materi, kata-kata motivasi, fakta ilmiah, konsepkonsep penting "untuk diingat", contoh soal, latihan, Pada akhir BAB dilengkapi dengan ringkasan atau rangkuman, Glosarium, dan uji kompetensi dan refleksi berupa mengukur ketercapaian siswa terhadap materi. Di akhir buku terdapat Daftar pustaka sebagai referensi dalam pembuatan buku tersebut sistem periodik unsur, dengan cover background biru, tulisan times new romans, ukuran font 12, dan jenis kertas A4.

\section{Analisis penuntun praktikum kimia yang telah dikembangkan}

Adapun hasil dari analisis penuntun praktikum kimia yang telah divalidasikan oleh dosen dan guru adalah sebagai berikut:

\section{Standar kelayakan isi}

Pada Gambar 2terlihat bahwa nilai ratarata standar kelayakan isi menurut pendapat dosen abjad A dan E yaitu cakupan materi dan merangsang keingintahuan memiliki nilai tertinggi sebesar 4,67 demikian halnya juga menurut pendapat guru abjad E memiliki nilai 
tertinggi sebesar 4,7 artinya sangat layak dan tidak perlu direvisi.

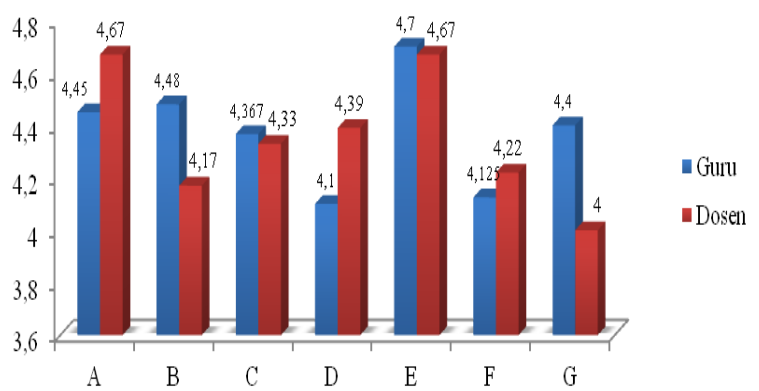

Gambar 2. Nilai rata-rata standar kelayakan isi

\section{Standar kelayakan bahasa}

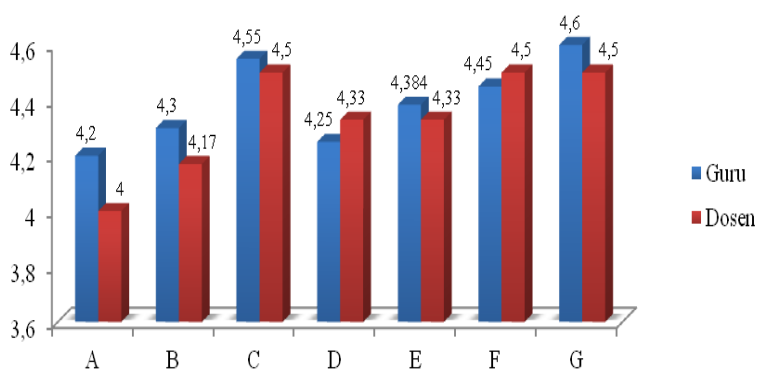

Gambar 3. Nilai rata-rata standar kelayakan bahasa

Pada Gambar 3 terlihat bahwa nilai ratarata standar kelayakan bahasa menurut pendapat dosen abjad $\mathrm{F}$ yaitu kesesuaian dengan istilah bahasa Indonesia dan $\mathrm{G}$ yaitu penggunaan istilah dan simbol/lambang memiliki nilai tertinggi 4,5 sementara menurut pendapat guru abjad $G$ yaitu penggunaan istilah dan simbol/lambang memiliki nilai tertinggi sebesar 4,6 artinya sangat layak dan tidak perlu direvisi.

\section{Standar kelayakaan penyajian}

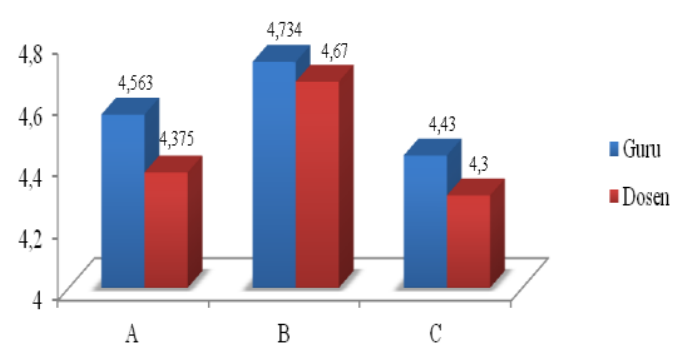

Gambar 4. Nilai rata-rata standar kelayakan penyajian

Pada Gambar 4 terlihat bahwa nilai ratarata standar kelayakan penyajian menurut pendapat dosen abjad B yaitu pendukung penyajian materi 4,67 demikian halnya menurut pendapat guru abjad B memiliki nilai tertinggi sebesar 4,734 artinya sangat layak dan tidak perlu direvisi.

\section{Standar kelayakan kegrafikaan}

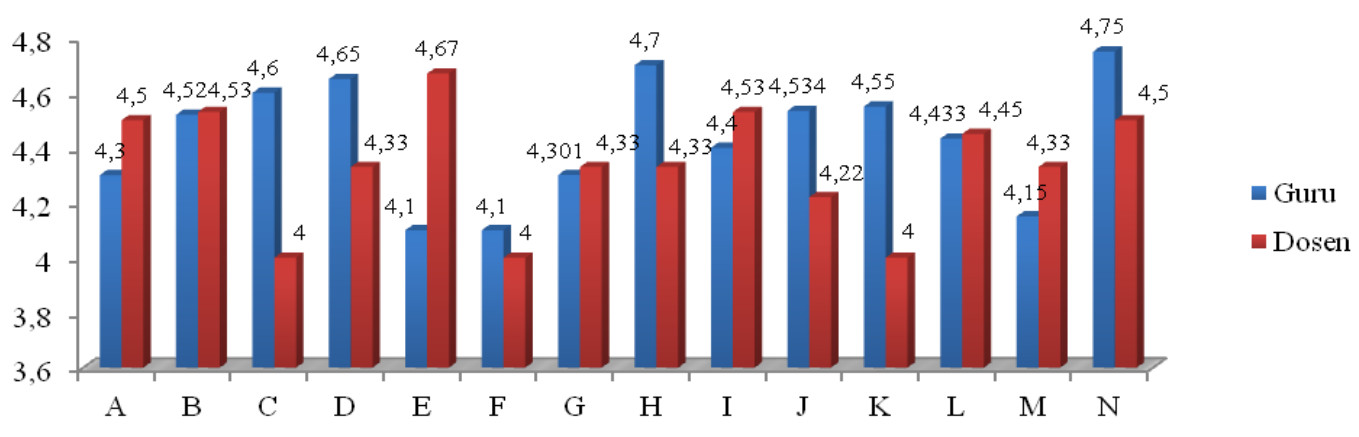

Gambar 5. Nilai rata-rata standar kelayakan kegrafikaan

Pada Gambar 5 terlihat bahwa nilai ratarata standar kelayakan kegrafikaan menurut pendapat dosen abjad E yaitu ilustrasi kulit buku memiliki nilai tertinggi sebesar 4,67 sementara menurut pendapat guru abjad $\mathrm{N}$ yaitu Ilustrasi isi menimbulkan daya tarik memiliki nilai tertinggi sebesar 4,75 artinya sangat layak dan tidak perlu direvisi.

Nilai-nilai karakter siswa dalam buku ajar yang dikembangkan oleh validator
Pada gambar histogram di atas terlihat bahwa rata-rata skor nilai karakter menurut pendapat dosen adalah rasa ingin tahu, kreatif dan tanggung jawab memiliki nilai tertinggi yaitu 4,67. Sedangkan menurut guru nilai karakter tanggung jawab memiliki nilai tertinggi yaitu sebesar 4,5 , disusul dengan karakter disiplin, rasa ingin tahu dan menghargai prestasi sebesar 4,4 . 


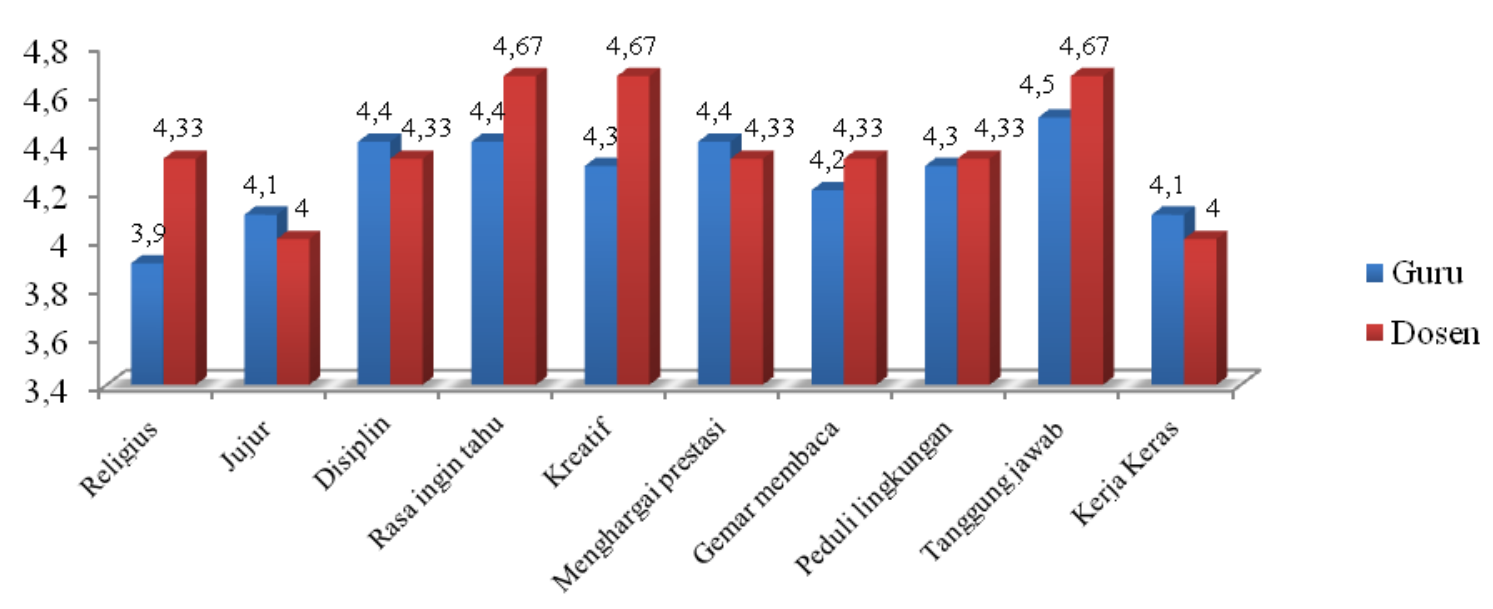

Gambar 6. Rata-rata skor nilai karakter validator

Nilai-nilai karakter siswa dalam buku ajar yang dikembangkan oleh validator

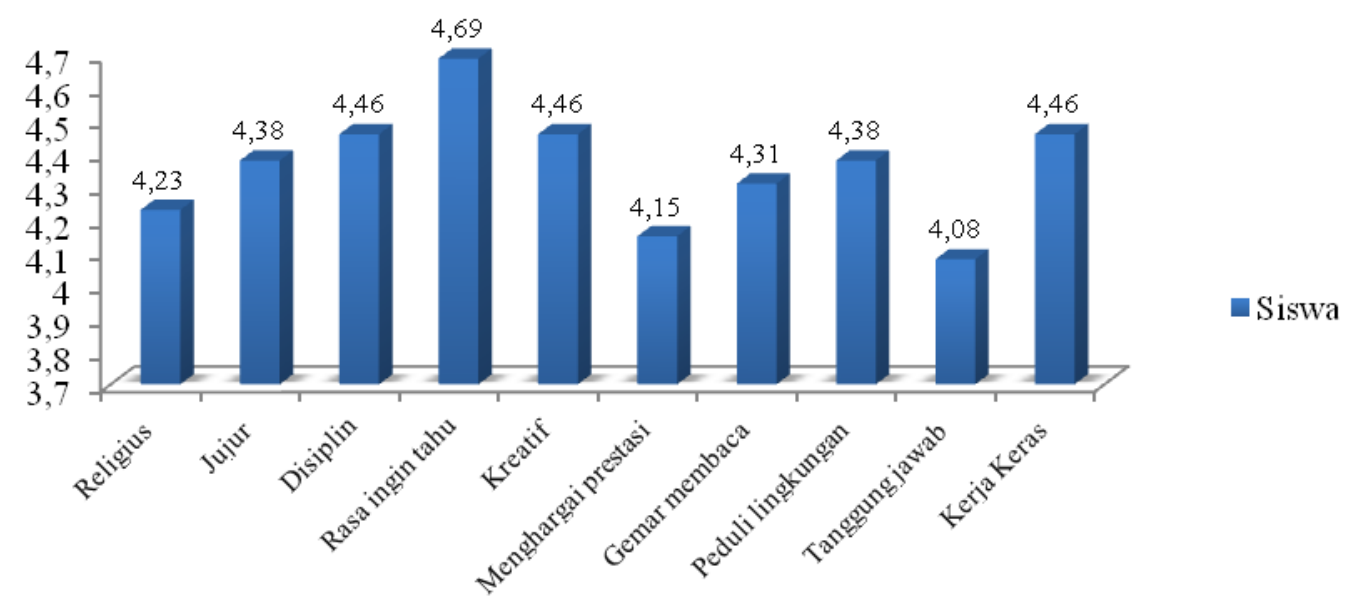

Gambar 7. Rata-rata skor nilai karakter responden siswa

Pada gambar histogram di atas terlihat bahwa karakter rasa ingin tahu merupakan nilai yang tertinggi yaitu 4,69 artinya sangat layak dan tidak perlu direvisi. Meskipun demikian karakter lain terkembang jugaseperti kerja keras, disiplin dan kreatif.

\section{Aplikasi buku ajar kimia berdasarkan kurikulum 2013 terhadap peningkatan hasil belajar siswa}

Untuk mengetahui keefektifan buku ajar kimia terinternalisasi nilai-nilai karakter siswa terhadap hasil belajar kimia siswa maka dilakukan uji coba dengan menggunakan instrumen tes kepada siswa. Soal yang digunakan sebagai instrumen sudah standar dan valid untuk digunakan. Untuk mengetahui peningkatan hasil belajar siswa yang diajarkan dengan menggunakan buku ajar kimia ini maka dilakukan penelitian terhadap siswa SMA kelas XI semester ganjil. Penelitian dilakukan di SMA Islam Ulunnuha medan. Penelitian ini menggunakan buku ajar kimia terinternalisasi karakter siswa yang dikembangkan berdasarkan kurikulum 2013.

Pada awal penelitian terlebih dahulu peneliti memberikan tes awal pada siswa yang bertujuan untuk mengetahui kemampuan awal siswa, sedangkan postest dilakukan setelah siswa diberikan perlakuan. Data yang diperoleh berupa peningkatan nilai hasil belajar siswa yang didapatkan dari nilai pretest dan nilai postest.

$\mathrm{N}-$ gain $=\frac{\text { Skor postest }- \text { skor pretest }}{\text { Skor maksimum-skor pretest }}$

Adapun nilai rata-rata untuk pretes adalah sebesar 30,38 dan nilai rata-rata postes adalah sebesar 78,84. Berdasarkan data hasil pretest dan postest ditemukan ada perbedaan rata-rata nilai pretest dan postest siswa pada pelajaran kimia, sehingga perlu ditentukan nilai gain hasil belajar kimia pada 
kelas tersebut. Perolehan nilai rata-rata gain di sekolah SMA Islam Ulnunnuha kelas XI IPA-A adalah 0,69. Dapat disimpulkan bahwa nilai rata-rata gain ternormalisasi termasuk dalam kategori sedang.

\section{Uji hipotesis}

Berdasarkan hasil perhitungan uji Hipotesis, maka diperoleh nilai hasil belajar kimia siswa yang diajar menggunakan buku ajar kimia SMA/MA kelas XI semester ganjil terinternalisasi nilai-nilai karakter siswa lebih baik dari nilai KKM. Hasil hipotesis diperoleh sebesar o,011. Hal ini menunjukkan bahwa harga sign< $<0,05 \quad(0,011<0,05)$, maka $\mathrm{Ha}$ diterima. Dapat disimpulkan bahwa kualitas buku ajar kimia yang telah dikembangkan dalam penelitian ini lebih baik dari nilai KKM yang ada di sekolah.

\section{KESIMPULAN}

Berdasarkan hasil pembahasan penelitian yang telah diuraikan pada bab IV, maka dapat diambil kesimpulan sebagai berikut: (1) uji kelayakan 4 buku yang ada di pasaran berdasarkan standar BSNP diperoleh nilai rata-rata 3,37 dengan kriteria cukup valid tetapi perlu direvisi; (2) uji kelayakan buku oleh validator terhadap pengembangan buku ajar kimia SMA/MA kelas XI semester ganjil yang dikembangkan berdasarkan standar BSNP nilai rata-rata sebesar 4,407 dilihat dari kriteria validitasnya buku ajar tersebut sudah valid dan tidak perlu direvisi; (3) uji kelayakan buku oleh validator terhadap pengembangan buku ajar kimia SMA/MA kelas XI semester ganjil yang dikembangkan telah terinternalisasi nilai-nilai karakter siswa di dalamnya dengan skor rata-rata 4,32; (4) uji kelayakan buku berdasarkan internalisasi nilai-nilai karakter oleh siswa terhadap buku ajar kimia yang telah dikembangkan sangatlah positif dengan rata-rata 4,36 mereka memilih bahwa karakter rasa ingin tahu yang paling tinggi yaitu sebesar 4,69 yang menuntun siswa untuk tahu lebih luas tentang kimia dan hubungannya dengan kehidupan sehari-hari; (5) peningkatan hasil belajar kimia setelah belajar dengan menggunakan buku ajar kimia SMA/MA kelas XI semester ganjil pada pokok bahasan kesetimbangan kimia diperoleh nilai rata-rata gain antara pretes dan postes adalah sebesar o,69 yang artinya bahwa kriteria nilai rata-rata gain ternormalisasi termasuk dalam kategori sedang; dan (6) hasil belajar kimia siswa yang menggunakan buku ajar kimia
SMA/MA kelas XI semester ganjil terinternalisasi nilai-nilai karakter siswa lebih baik dari nilai KKM. Ditentukan dari uji $\mathrm{t}$ dengan satu sampel atau One Sample T-Test diperoleh nilai sig<0,05 yaitu sebesar o,011 yang artinya sangat signifikan dalam penggunaan buku ajar kimia yang telah dikembangkan.

\section{DAFTAR PUSTAKA}

Abdinsyah, dan Dasim Budimansyah, (2012), Internalisasi Nilai Peduli Lingkungan Melalui Pembelajaran Berbasis Kearifan Lokal, Integritas, 1(1): 1-16

Afandi, Rifki., (2011), Integrasi Pendidikan Karakter dalam Pembelajaran IPS di Sekolah Dasar, Pedagogia, 1 (1):85-98

Amir, Syarifuddin., (2013), Pancasila As Integration Phylosophy of Education and National Character, International Journal of Scientific and Technology Research, 2(1):54-57

Aqib, Z., (2012),Pendidikan Karakter di Sekolah (Membangun Karakter dan Kepribadian Anak). Bandung : Yrama Widya

BSNP, 2006, Panduan KTSP Jenjang Pendidikan Dasar dan Menengah, Jakarta: Depertemen Pendidikan Nasional

Chaplin, J.P., (2002), Kamus Lengkap Psikologi, Jakarta: Raja Grafindo Persada.

Kemendiknas., (2011), Panduan Pelaksanaan Pendidikan Karakter, Jakarta : Badan Penelitian dan Pengembangan Pusat Kurikulum dan Perbukuan

Mardiansyah, Yopi., (2013), Pembuatan ModulFisika Berbasis TIK untuk Mengintegrasikan Nilai Pendidikan Karakter Dalam Pembelajaran Siswa SMAN 10 Padang Kelas X Semester I, Pillar of Physics Education, 1 (1):30-38.

Mulyasa, H.E., (2013),Pengembangan dan Implementasi Kurikulum 2013, Bandung, Remaja Rosdakarya.

Padmo, D., (2004), Teknologi Pembelajaran: Peningkatan Kualitas Belajar Melalui Teknologi Pembelajaran, Ciputat: Pusat Teknologi Komunikasi danInformasi Pendidikan

Putra, G., Nunuk, S., \& Suharno. (2013), Pengembangan Model Internalisasi Nilai Karakter dalam IPS Melalui VCT (Value Clarification Technique) di SMP se Solo Raya, Jurnal Teknologi 
JPKim Vol. 8, No. 3, 2016

Pendidikan dan Pembelajaran, Matematika. Tim Pascasarjana 1(3):389-397

Universitas Gorontalo.

Sugiyono, 2010, Metode Penelitian Pendekatan kuatitatif, Kualitatif dan $R \& D$, Bandung: Alfabeta

Uno, H.B., (2014). Pengembangan Perangkat Pembelajaran Terinternalisasi Karakter Untuk Meningkatkan Belajar

Wibawa, Andi Setyo., Saptorini., dan Retno Sri Iswari, (2013), Pengembangan Bahan Ajar IPA Terpadu Berbasis Pendidikan Karakter Pada Tema Dampak Bahan Kimia Rumah Tangga Terhadap Lingkungan, Unnes Science Education Journal, 2 (1) 